\title{
FARMERS' PERCEPTION AND EXTENT OF USE OF INSECTICIDES IN CABBAGE PRODUCTION IN GIWA AND ZARIA LGAs OF KADUNA STATE
}

\author{
OMOKORE, D. F., AKINOLA, M. O. and ATIYONG, E. B. \\ Dept. of Agric. Economics \& Rural Sociology, Ahmadu Bello University, Zaria, \\ Nigeria \\ Correspondence e-mail: daveomokore@yahoo.com
}

\begin{abstract}
Farmers have been skeptical and reluctant in the use of pesticides in vegetable production for fear of contamination and negative effects on humans during consumption. This study focuses on identifying farmers' perception and extent of use of insecticides in cabbage production. Using structured questionnaire, primary data were collected from 70 randomly selected cabbage farmers in Giwa and Zaria LGAs of Kaduna State. The data collected were analysed using descriptive statistics and Likert scale of measurement. The results show that most (70\%) of the farmers use Karate, followed by neem extract (66\%) which is usually mixed with the chemicals. Nearly all (94\%) of the respondents perceived that the use of the insecticides are highly effective on insect control, pollute the air and improves the market value of cabbage due to lack of perforations and insect excrements on them. Respondents suggested that farmers should be adequately trained on insecticide use and subsidise its cost to make it readily accessible.
\end{abstract}

Keywords: Perception, Insecticide, Cabbage

\section{INTRODUCTION}

Efforts have been made in Nigeria, since independence, to achieve food security and steps have been taken by policy makers, research institutes and other stakeholders to increase food production by introduction of improved farm technologies like pesticides and the use of improved varieties of seeds. However all these efforts have not made a substantial impact on the Nations agricultural sector (Solomon, 2008).

In most developing countries, especially in Africa, the use of pesticides in agricultural production is low. This has been attributed to illiteracy, poor infrastructural facilities, poverty and accessibility (Richardson, 2003). 
In particular, farmers have been so skeptical and reluctant in the use of pesticides in vegetable production for fear of contamination and negative effects on humans during consumption. This study, therefore, focuses on identifying farmers' perception and extent of use of insecticides in cabbage production, with the aim of encouraging it, increasing productivity and bettering the income and livelihood of farmers.

\section{PROBLEM STATEMENT}

Insect pest control is important in cabbage production especially in commercial production where product appearance is a success driver to cabbage farmers. In Zaria Area of Kaduna State, cabbage free from insect perforations, insect excrement and carcasses are bought by consumers while contaminated cabbage constitutes loss to cabbage growers. Chemical insecticides have been the most readily available and fastest plant protection technology available for cabbage growers both for preventive and control (Chathan, 1992). The use of insecticides by cabbage growers provides an effective means of maintaining the wholesomeness of the cabbage crop from transplanting up to harvest period. Insecticides such as Combat, Karate, Perithriod, Serin and Malation have been used over the years for insect control in Zaria (Foster et al, 2002). However, farmers' use of these insecticides has been with mixed feeling, reluctance and means of last resort. With the availability of these chemicals in the market, why this reluctance in use and consequently the continuous production of cabbage with perforations and other attributes that causes its low value? The study is aimed therefore at investigating farmers' perception and extent use of insecticides in cabbage production in Zaria area.

\section{THE CABBAGE CROP History, Production and Pest Management}

Cabbage, Barcica Oleraceal L., is from a group of plants known as the Cole crop, derived from the Middle Age English Word "Col". The Romans called the crop "caulis" while the Greeks called them "Kaulion". All these words mean stem. Other plants in this group include cauliflower, kale, collards, broccoli, kohlrabi and Brussels's sprout. Wild Cole corps is found growing around the Mediterranean and Atlantic coastal Europe. Cabbage and kale are thought to have their origin from Western Europe, while broccoli and cauliflower from the Mediterranean region. Cabbage and kale are the Coles to be first domesticated, about 2,000 years ago before then they were collected from the wild and used for medicine (Bewick, 1994).

Cabbage is a soft plant which may be eaten with fish, meat, salad, other preparation or eaten raw (Lawal, 1998). Cabbage production has been playing a vital role in both human and animal nutrition, poverty reduction and in changing farmers' socioeconomic status (Lawal, 1998). Cabbage is fairly low in calorie, a good source for many minerals particularly potassium, relatively high in vitamin $\mathrm{C}$ and $\mathrm{A}$, relatively low in protein content, it makes food palatable and supplies good enrichment to the body (Bewick, 1994). Uncooked cabbage is high in glutamine, an amino acid essential for 
intestinal health. Cabbage contains vitamin K (essential for blood clothing protein), potassium (which help regulates blood pressure) and quartering antioxidant that is a natural antihistamine that can benefit allergy sufferers (Earth clinic, 2008).

Cabbage is a cool season crop planted early or late in the growing season. Best quality cabbage is produced in the day time temperature of $70-80^{\circ}$, sunny conditions and moist, fertile, week-drained soil. Cabbage can be propagated by direct seeding, mechanical methods or by seedling transplant. Commercial propagation favours transplanting while fresh market growers chose to direct seeding. Cabbage needs irrigation water each week, requiring $120-150 \mathrm{~kg}$ of nitrogen, $50-100 \mathrm{~kg}$ of phosphorous and $120-180 \mathrm{~kg}$ of potassium per acre with addition of potassium and phosphorous based on test of soil. Hand hoeing can be done to control weeds or use of herbicides for commercial producers. Fields are scouted for insects, weeds and disease throughout growing season. Cabbage can either be harvested by hand or mechanically (Rourke et al, 2001).

The insect pest of cabbage in Northern Nigeria includes:

- $\quad$ Cabbage Looper (Trichoplusiani)

- Diamond back moth(DBM)(Plutellaxylostella)

- Imported Cabbage Worm (Pieris rapea).

- Cabbage Maggot (Delia radicum)

- Flea Beetles (Phyllotreta spp)

Even though quality may vary, cabbage that is produced for the fresh market consumers have a very low tolerance to insect pest damage (Foster and Flood, 1995). Pest management should begin with treatment of soil in the nursery. As the medium of growth, the soil is important target for pest attack in the nursery. Important pathogens of economic importance like bacterial wilt, root knot nematodes, sclerotium wilt and fusarium wilt live in the soil. When seedlings are raised in the nursery, soil infested with these pathogens should be avoided or treated. When seedlings are raised in boxes they should be sterilized by heating the seed bed soil. The seed bed should be fumigated against nematodes, fungi and soil insects.

There are resistant cabbage varieties against some of the pathogens that the cabbage crop is exposed to in the filed. When varieties from such cultivars are used in nursery, usually seedlings have the required vigor to withstand pest attack at the beginning of their life circle. Protective chemical should be used to treat seed for planting (Alao, 1989).

\section{RESEARCH METHODOLOGY}

This study was focused on cabbage farmers in Giwa and Zaria LGAs having farming activities in the fadama (floodable plains) areas. Two districts were purposively selected from the two LGAs, namely Shika district in Giwa LGA and Dizara district in Zaria LGA, because farmers in the fadama areas of these districts grow cabbage. Simple 
random technique was used to select a total of 70 cabbage farmers from these two districts: 30 farmers were selected from Shika district while 40 farmers were selected from Dizara district. This selection was based on the size of cabbage farmers in each district. Only farmers involved in cabbage production (solely or mixed) were selected for the study.

Primary data were collected from farmers, using questionnaire, and analysed using descriptive statistics and Likert scale measurement. Options were provided for the respondents to which best reflects their views on the use of insecticides on cabbage production. Gross margin analysis was used to ascertain the economic implication, i.e. the cost and returns of cabbage production.

\section{RESULTS AND DISCUSSION}

Farmers' level of awareness and source of knowledge of insecticides use in cabbage production were probed into, and the results were shown in Tables 1 and 2 below.

Table1. Distribution of Respondents according to Level of Awareness of Insecticides used for Cabbage Production

\begin{tabular}{l|c|c}
\hline Insecticide & No. of Respondents aware & $\%$ \\
\hline Combat & 20 & 28.57 \\
karate & 36 & 51.42 \\
Perithriod & 10 & 14.29 \\
Others (neem extract) & 4 & 5.71 \\
\hline Total & 70 & 100 \\
\hline
\end{tabular}

Table 1 shows that respondents are mostly aware of the use of Karate $(51 \%)$ for insect pest control, followed by Combat (29\%), Perithriod (14\%) and botanicals (6\%). This is likely due to the name Karate, which is a martial art that farmers are conversant with as a result of the films they watch during their leisure.

Table 2. Distribution of Respondents according to Source of Knowledge on Insecticides used.

\begin{tabular}{l|c|c}
\hline Source & Frequency & $\%$ \\
\hline Other farmers & 60 & 85.72 \\
Radio & 4 & 5.71 \\
Extension agents & 6 & 8.57 \\
\hline Total & 70 & 100 \\
\hline
\end{tabular}


Table 2 shows that about $86 \%$ of the respondents got the knowledge of the use of insecticides through other farmers, while those who got awareness through extension agents were about $9 \%$. This shows that the respondents were not frequently reached by extension agents to educate them on insecticide use on cabbage production.

\section{Extent of use of Insecticides by Cabbage Farmers}

Table 3: Extent of use of Insecticides

\begin{tabular}{l|c|c|c}
\hline Insecticides & Weighted score (total) & Mean score & \% \\
\hline Combat & 197 & 2.8 & 56.3 \\
Karate & 126 & 1.8 & 35.3 \\
Pirethroid & 127 & 1.8 & 36.3 \\
Others (neem extract) & 266 & 3.8 & 76 \\
\hline
\end{tabular}

Table 3 shows that Combat and Neem extract are significantly used for insect control by farmers in the study area. About $56 \%$ of the respondents use Combat, while $76 \%$ used Neem extract. The high extent of use of insecticide is likely due to high insect attack on cabbage from the nursery bed up to harvest. However, the high level of use of neem extracts is noteworthy, and further probing of the respondents revealed that farmers mix it with other insecticides before application for better insect control.

Farmers' perceptions on Insecticide use Table 4: Farmers Perceptions on Insecticide use (Mean score)

\begin{tabular}{l|c|c|c}
\hline Perceptions & Weighted score & Mean score & \% \\
\hline Effective in controlling insect pest & 332 & 4.7 & 94 \\
Makes farm and cabbage crop neat & 310 & 4.4 & 88 \\
Indirectly enhances demand for cabbage & 322 & 4.6 & 92 \\
Could cause air and water pollution & 334 & 4.8 & 96 \\
\hline
\end{tabular}

Table 4 shows farmers' perception on the use of insecticides in controlling insect pests of cabbage. Most (94\%) of the respondents agreed that insecticides are effective in controlling insect pests of cabbage. Similarly, nearly all $(96 \%)$ of the respondents perceived that the use of insecticides causes environmental pollution. This is largely due to the smell they perceived, and sneezing caused by the insecticides.

Also, majority of the respondents $(88 \%)$ perceived neatness of farms and cabbage crop due to the use of insecticides, while nearly all the respondents (92\%) perceived and even experienced high demand for their cabbage crops, which they attributed to the use of insecticides. 


\section{CONCLUSION}

In the light of this study, it could be concluded that farmers are highly aware of the available insecticides for cabbage production, mainly through information from fellow farmers. Karate is the most frequently used of all the insecticides. Nearly all the respondents perceived that the use of insecticides could cause pollution of the environment, but effective in controlling insect pests and enhance product quality/market value.

\section{RECOMMENDATIONS}

From the results of this study, it is recommended that Agricultural extension agents should be trained and encouraged, through adequate incentives, to reach out and adequately train farmers on the use of insecticides. This is imperative not only to enhance their capacity but also streamline their perception and orientation towards insecticide use.

\section{REFERENCES}

Alao J.A (1989). Community Structure and Modernization of Agriculture: An Analysis of Factors Influencing the Adoption of farm Practices Among Nigeria farmers, Unpublished PhD. Dissertation, Cornell University, Ithaca.

Bewick, A. Thomas (1994). Cabbage Diseases and Production, University of Florida Cooperative Extension Service, Fact sheet HS-712.

Chatham (1992), Integrated Pest Management in Developing Countries: Experience and Prospects, Natural Resources Institute (NRI).

Earth Clinic (2008). Folk Remedies and Holistic Cures. Http//www.earthcliniccabbagecures.com. Retrieved 10th March 2008.

Foster, R, and Flood, B. (1995). Vegetable insect management. Meister publishing company. Willoughby, Ohio.

Foster, R., Engel, D., Maynard, E., Weinzierl, R., Barbados, M., Taber, H., Jett, L. W. and W. Hutchison (2002). Mid-West Vegetable Production Guide for Commercial Growers, University of Minnesota-Extension service, USA.

Lawal. R. (1998) Adoption of Recommended Pest and Disease Control Technologies in Vegetable Crops among Farmers in Sabon Gari L.G.A., Unpublished B. Agric. Research Project, Ahmadu Bello University, Zaria. 
Richardson, D. (2003). Agricultural Extension Transforming ICTs? Championing Universal Access, Background Papers for CTCs Observation 2003.

Rourke, P.K., Bennel, V. W., Hutchison, W. D. (2001). Minnesota Cabbage Crop Profile, University of Minnesota, St. Paul, MN.

Solomon, O. (2008). Assessment of Peasant Attitude to the Use of Solid Waste as Substitute for Chemical Fertilizer for Agricultural Production: A Case Study of Sabon Gari LGA of Kaduna State. Unpublished B. Agric. Project, Department of Agricultural Economics And Rural Sociology, Ahmadu Bello University, Zaria. 